\title{
Class Actions and Statutes of Limitations
}

Rule 23 of the Federal Rules of Civil Procedure provides that "[a]s soon as practicable after the commencement of an action brought as a class action," the trial judge shall determine whether the suit should be allowed to continue as a class action. ${ }^{1}$ In practice, however, the period between filing and the decision on class certification can be rather long-often more than six months. ${ }^{2}$ During this delay the statute of limitations may expire. Whether asserted class members are barred by the statute of limitations in these circumstances is a question that has troubled many courts.

In American Pipe \& Construction Co. v. Utah, ${ }^{3}$ the Supreme Court held that in cases where the class subsequently is certified, the class members should be deemed to have been "in court" from the date of the filing of the class action. ${ }^{4}$ Should class action status

1 FED. R. Crv. P. 23(c)(1). Rule 23 specifies the criteria the trial court should consider:

(a) Prerequisites to a Class Action. One or more members of a class may sue or be sued as representative parties on behalf of all only if (1) the class is so numerous that joinder of its members is impracticable, (2) there are questions of law or fact common to the class, (3) the claims or defenses of the representative parties are typical of the claims or defenses of the class, and (4) the representative parties will fairly and adequately protect the interests of the class.

In addition to these requirements, rule $23(\mathrm{~b})$ sets forth the possible grounds for justifying the use of a class action: (1) the question involved must be resolved by a single suit, because there is a danger that absent parties' rights could be effectively disposed of, or that the defendant could be subjected to inconsistent obligations; (2) classwide declaratory or injunctive relief is appropriate; or (3) a class action is superior to all other available methods of resolving the disputes.

See Note, The Rule 23(b)(3) Class Action: An Empirical Study, 62 Geo. L.J. 1123, 1141-43 (1974) (six months as average time between filing and motion for certification). There is a delay between the original filing of the suit and the motion by a party either to grant or to deny class action status, and there is a further delay while the court considers the motion.

- 414 U.S. 538 (1974).

- Id. at 545-52. The Court reasoned that such a tolling rule was vital to the preservation of the class action device:

[Not to toll for class members] would frustrate the principal function of a class suit, because then the sole means by which members of the class could assure their participation in the judgment if notice of the class suit did not reach them until after the

- running of the limitation period would be to file earlier individual motions to join or intervene as parties-precisely the multiplicity of activity which Rule 23 was designed to avoid in those cases where a class action is found "superior to other available methods for the fair and efficient adjudication of the controversy." 
be denied, however, the position of the asserted class members is problematic. The Supreme Court in American Pipe provided guidelines for answering this question, ${ }^{5}$ but they have proved unclear and difficult to apply.

This comment seeks to clarify the position of asserted class members when class certification is denied after the running of the statute of limitations. Three areas of controversy will be explored. The comment will first examine the scope of the American Pipe tolling rule, and the difficulties of satisfying its dual goals as those goals currently are interpreted by the lower courts. Problems in the Court's prescribed method of tolling a statute of limitations will then be discussed. Finally, the comment will deal with the controversy over available methods of claiming tolling benefits under American Pipe.

\section{American Pipe}

In 1969 the state of Utah filed an antitrust class suit, charging a price-fixing conspiracy among manufacturers and distributors of concrete and steel pipe in the western United States. The suit was

Id. at 551 (quoting FeD. R. Crv. P. 23(b)(3)).

In discussing suits granted class certification after the running of the statutory period, the Court devoted much of its attention to distinguishing current class action procedure from that employed before the 1966 amendments. Prior to 1966, class actions were of three types: true, hybrid, and spurious, see Fed. R. Civ. P. 23 (1938), reprinted in 39 F.R.D. 94-95 (1966). A class member in a spurious class action had the power of "one-way intervention": if the representative was successful, class members could then intervene and share in the favorable judgment; if the representative lost, class members were not bound by the judgment and could sue individually. See Kalven \& Rosenfield, The Contemporary Function of the Class Suit, 8 U. CHI. L. REv. 684 (1941). This aspect of spurious class actions led to a disagreement among the courts over the effect of the filing of a class claim on the statute of limitations for absent class members. The majority of courts emphasized the representative nature of the class suit, e.g., Escott v. Barchris Constr. Corp., 340 F.2d 731 (2d Cir.), cert. denied, 382 U.S. 816 (1965), or desired to protect the absent class members' ability to rely on the class suit and benefit by it, e.g., Union Carbide \& Carbon Corp. v. Nisley, 300 F.2d 561, 588-89 (10th Cir. 1961), cert. dismissed, 371 U.S. 801 (1962); York v. Guaranty Trust Co., 143 F.2d 503, 529 (2d Cir. 1944), rev'd on other grounds, 326 U.S. 99 (1945). Other courts emphasized the unfairness of one-way intervention and declared that the spurious class action was nothing more than a "permissive joinder device" for essentially separate claims, e.g., Athas v. Day, 161 F. Supp. 916, 919 (D. Colo. 1958); see Comment, Class Actions Under New Rule 23 and Federal Statutes of Limitations: A Study of Conflicting Rationale, 13 VnL. L. Rgv. 370, 378-80 (1968). Hence, they concluded, each class member must individually satisfy the statute of limitations. The American Pipe court declared that the unfairness of one-way intervention had been removed from the amended rule 23, and thus treatment of a class suit as a "permissive joinder device" was no longer justified. 414 U.S. at 550 .

s 414 U.S. at 552-56. 
brought on behalf of public agencies in Utah, and on behalf of other state agencies in the western area who were end users of concrete and steel pipe. Utah had filed the action with eleven days left to run in the statutory period. ${ }^{6}$ Eighteen months later the defendants moved, pursuant to rule 23(c)(1), ${ }^{7}$ for an order declaring that the suit could not be maintained as a class action. The district judge granted the motion, holding that while the complaint alleged a class of more than 800 members, he knew "[f]rom prior actual experience ... involving the same alleged conspiracy"s that the actual number of public agencies that might have been injured by the alleged conspiracy was much smaller. The judge thus ruled that the class was not so numerous as to make joinder of all class members impracticable, as is required by rule $23(\mathrm{a})(1),{ }^{9}$ and he denied class certification. ${ }^{10}$ Eight days after the entry of that order, more than sixty towns, municipalities, and water districts moved to intervene in the suit. The trial court denied the motions on the ground that the statute of limitations had run. ${ }^{11}$

The Ninth Circuit reversed, holding that "as to members of the class Utah purported to represent . . . suit was actually commenced by Utah's filing."12 The court emphasized that when the trial court denied class action status because the class was not so numerous as to make joinder impracticable, it was simply expressing a preference that the suit should take a different form-a joint suit instead of a class action. The intervenors were merely attempting to comply with the trial court's wish. ${ }^{13}$

The Supreme Court affirmed the court of appeals, but offered a different and more thorough analysis of the general problem that arises when class status is denied after the running of the statutory period. ${ }^{14}$ This analysis centered on two considerations.

The first consideration was the protection of the class action device. The Court characterized the trial court's denial of class certification as a decision based on "subtle factors," not easily fore-

- See id. at 542.

${ }^{7}$ FED. R. Crv. P. 23(c)(1).

${ }^{8}$ Utah v. American Pipe \& Constr. Co., 49 F.R.D. 17, 21 (C.D. Cal. 1969). The same judge had presided over similar civil antitrust suits brought by other state governments. See id. at 18-19.

- See note 1 supra.

1049 F.R.D. at 21.

11 Utah v. American Pipe \& Constr. Co., 50 F.R.D. 99 (C.D. Cal. 1970).

12 Utah v. American Pipe \& Constr. Co., 473 F.2d 580, 584 (9th Cir. 1973).

1s Id. at 583-84.

14414 U.S. at 552-56. 
seen by class members. ${ }^{15}$ If these class members were not protected from the statute of limitations after such a denial of class action status, great harm to the class action procedure would result. ${ }^{16}$ "Potential class members would be induced to file protective motions to intervene or join in the event that a class was later found unsuitable."17 This "multiplicity of activity," the Court said, was precisely what many class actions were designed to prevent. ${ }^{18}$

The Court's second consideration involved one of the basic reasons for having a statute of limitations, the concept that a potential defendant should have timely notice of any action brought against him. The claim of the named plaintiff in American Pipe was sufficiently typical of the class claims to ensure that the defendant had received adequate notice, within the statutory period, of the claims against him. ${ }^{18}$ The Court thus reasoned that its decision to toll honored the notice rationale underlying the limitations requirement.

The analytical framework derived from these two considerations has been aimed at protecting both the vitality of the class action suit from a needless "multiplicity of activity," and the integrity of the notice requirement underlying any statute of limitations. The lower courts, however, have had difficulty applying this framework and have reached inconsistent results in several important respects.

${ }^{18}$ Id. at 553 .

16 Id.

12 Id.

I Id. at 551. When the Court used this language, it was discussing the problem of class suits that are granted class action status after the running of the statutory period. See note 4 supra. The Court applied this same rationale two pages later, 414 U.S. at 553, when it discussed class suits denied certification after the running of the statutory period.

1 414 U.S. at 554-55. The Court based its analysis of the notice given to the defendant on the trial court's determination of class certification questions. Because the trial court determined that the named plaintiff's claim was typical of the class, FED. R. CIv. P. 23(a)(3), and that he would adequately represent the interests of the class, id. 23(a)(4); see note 1 supra, the Court concluded that the defendant had received adequate notice for purposes of the statute of limitations. Whether the Court thought the reverse would also be true-that the defendant could not be considered to have received adequate notice if the representative had not satisfied those class action requirements-is not clear from the opinion.

When the Court held that class members are protected when a class action is granted class certification after the running of the statue of limitations, it did not discuss the question of notice. That is explained, however, by the Court's analysis of the notice question when class suits are denied certification after the running of the statute. When certification is granted, the requirements of typicality and adequate representation must have been satisified. Thus the defendant must be considered to have received adequate notice in any class suit that is granted class certification. 


\section{The Proper Application of the Tolling Rule}

The first difficulty courts have faced in applying American Pipe concerns when this tolling rule should be applied. Two approaches have been used, and neither is consistent with the entire rationale of American Pipe.

\section{A. Emphasis on the Class Action}

One approach concentrates solely on the first consideration of American Pipe: the protection of the class action device. If the reason for denial of class certification in the present suit was based on sufficiently subtle factors, the courts must toll the running of the statute of limitations for all asserted class members. ${ }^{20} \mathrm{~A}$ refusal to toll after such an unpredictable denial of class certification might spawn a multiplicity of motions by anxious class members in future suits. Many courts have read American Pipe even more broadly, believing that the courts must always toll for asserted class members; the reason for denial of class certification, and the subtlety of the factors leading to that decision, would be irrelevant. ${ }^{21}$ These courts ignore the possibility that the defendant received no notice of the claims presented by subsequent plaintiffs claiming tolling benefits of the class suit, and thus they disregard the second consideration of American Pipe. ${ }^{22}$

${ }^{20}$ Goldstein v. Regal Crest, Inc., 62 F.R.D. 571, 576-80 (E.D. Pa. 1974). See also Developments in the Law-Class Actions, 89 HARv. L. REv. 1318, 1449 (1976) [hereinafter cited as Class Actions].

${ }^{21}$ Susman v. Lincoln Am. Corp., 578 F.2d 866, 869 (7th Cir. 1978); Sanders v. John Nuveen \& Co., 524 F.2d 1064, 1074 n.23 (7th Cir. 1975), vacated, 425 U.S. 929 (1976); Peritz v. Liberty Loan Corp., 523 F.2d 349, 354 n.5 (7th Cir. 1975); Katz v. Carte Blanche Corp., 496 F.2d 747, 760-61 (3d Cir.) (en banc), cert. denied, 419 U.S. 885 (1974); Parker v. Bell Helicopter Co., 78 F.R.D. 507, 513 \& n.2 (N.D. Tex. 1978); Agostine v. Sidcon Corp., 69 F.R.D. 437, 448 n.13 (E.D. Pa. 1975); Jones v. Holy Cross Hosp. Silver Spring, Inc., 64 F.R.D. 586, 590 \& n.6 (D. Md. 1974); Morton v. Charles County Bd. of Educ., 373 F. Supp. 394, 396 (D. Md. 1974), aff'd, 520 F.2d 871 (4th Cir.), cert. denied, 423 U.S. 1074 (1975).

This may be the more sensible application of American Pipe, although it is not faithful to the actual reasoning of the case. If one of the purposes of class suits is that class members may wait passively, relying on their champion, it seems inconsistent to require class members to be aware of "unsubtle factors."

22 Admittedly, in many of these cases such a question may not have been presented by the defendant, or it may have been obviated because it was clear to all that the defendant must have received notice. Indeed, this comment argues, see text and notes at notes 36-39 infra, that in most cases it will be obvious that the defendant received notice of the plaintiff's claim. Courts also have interpreted American Pipe in this way in situations where the adequacy of notice would be in serious doubt, however. See Miller v. Central Chinchilla Group, Inc., 66 F.R.D. 411, 417 (S.D. Iowa 1975) (certification denied because common questions did not predominate); Jones v. Holy Cross Hosp. Silver Spring, Inc., 64 F.R.D. 586, 590 
The American Pipe Court clearly recognized that the basic policies of the statute of limitations must be satisfied before tolling benefits may be granted..$^{23}$ The Court also recognized timely notice to the defendant as one of those basic policies. ${ }^{24}$ Because "evidence has been lost, memories have faded, and witnesses have disappeared,"25 the defendant is prejudiced by the plaintiff's delay.

\section{B. Adequacy of Notice in Each Case}

Other courts have recognized the second consideration of American Pipe, and made a careful inquiry concerning whether the defendant received notice of a subsequent plaintiff's claim from the prior class suit. ${ }^{26}$ The leading example of this approach is McCarthy v. Kleindienst. ${ }^{27}$ It was uncertain in that case whether the defendant had received adequate timely notice of the claims of

\& n.6 (D. Md. 1974) (class "too amorphous"); Goldstein v. Regal Crest Inc., 62 F.R.D. 571, 576-80 (E.D. Pa. 1974) (common questions did not predominate).

${ }^{23}$ See 414 U.S. at 554 ("This rule is in no way inconsistent with the functional operation of a statute of limitations"); id. at 555 ("Since the imposition of a time bar would not in this circumstance promote the purposes of the statute of limitations, the tolling rule we establish here is consistent both with the procedures of Rule 23 and with the proper function of the limitations statute"). See also Dawson, Undiscovered Fraud and Statutes of Limitation, 31 Mrch. L. REv. 591, 594-95 (1933) (emphasis added) (footnote omitted):

For limitation acts are not drafted in the shape of particularized enactments, narrow in scope and employing language with reference to specific objectives of legislative policy. ... [T] that they bear little relation to the policy factors which should govern the limitation of actions. . . . This being the case, it is not surprising that courts, in applying the statutory formulas, should feel free to redefine them for the special purposes in hand, and should not hesitate to read in "implied exceptions," independent of specific statutory language and based on an assumed, though vaguely apprehended, policy behind limitation legislation.

24414 U.S. at 554-55. Legislatures and courts have not clearly expressed what the real function of a statute of limitations is. See Developments in the Law-Statutes of Limitations, 63 Harv. L. REv. 1177, 1185 (1950) [hereinafter cited as Statutes of Limitations]. The basic goal seems to be the protection of the defendant, although this is expressed in several different forms. The first variation of this theme is that the defendant would be substantially prejudiced in his defense of an ancient dispute. Because the evidence has been allowed to grow stale and the defendant received no warning of the suit, so that he might act to preserve evidence in his favor, he cannot present an adequate case. The second variation is that the defendant can reach a state of repose deserving of protection. "There comes a time when he ought to be secure in his reasonable expectation that the slate has been wiped clean of ancient obligations...." Id.

${ }^{25}$ Order of R.R. Telegraphers v. Railway Express Agency, Inc., 321 U.S. 342, 349 (1944).

${ }^{38}$ McCarthy v. Kleindienst, 562 F.2d 1269 (D.C. Cir. 1977); Haas v. Pittsburgh Nat'l

Bank, 526 F.2d 1083, 1097 (3d Cir. 1975).

${ }^{27} 562$ F.2d 1269 (D.C. Cir. 1977). 
some class members. The D.C. Circuit gave the trial court a broad mandate to consider all the facts and circumstances in determining the scope of notice given to the defendant. ${ }^{28}$

The problem with any careful inquiry into the notice question is that it will involve the consideration of subtle factors. When the court is to review all the circumstances of the case in determining which claims should be allowed, the result will be difficult to predict. Anxious class members would file protective motions as a result. In short, a careful consideration of the notice question leads to a violation of the "multiplicity" rule of American Pipe as it has been interpreted by the lower courts.

\section{Resolution}

The answer to this dilemma lies in a more practical examination of each of the American Pipe criteria. As each criterion is examined according to its actual effects, the two requirements of American Pipe can be made compatible.

1. Multiplicity. The American Pipe Court said that a refusal to toll the statute of limitations in the case before it would lead to protective motions-spurious motions to join or intervene, solely for protection from the statute of limitations-in subsequent class suits. It is unclear which of two phenomena actually concerned the Court. It may have been trying to prevent protective motions per se. Protective motions are wasteful, and the Court at one point characterized its tolling rule as necessary to avoid "needless duplication of motions."28 If this was the Court's concern, then American Pipe should be interpreted so as to avoid all unnecessary motions, and some courts have done so. ${ }^{30}$

Alternatively, the Court may have been seeking to avoid a "multiplicity of activity,"s1 which the protective motions in that

18 We will not here attempt to delineate with precision or finality the extent to which appellants should be permitted to intervene in this action. We think that this task is better performed by the district judge, after he has received the view of the parties and made further inquiry into the relationships between the claims of the named plaintiffs and those of appellants. Once he has determined the breadth of the notice provided by the class complaint and the degree to which defendants may have been prejudiced by the timing of the motion for intervention, he can, if necessary, limit or condition appellants' rights of intervention.

Id. at 1275 .

29414 U.S. at 555.

so See Wachovia Bank \& Trust Co. v. National Student Mktg. Corp., 461 F. Supp. 999, 1011-13 (D.D.C. 1978) (reading American Pipe to forbid duplicative suits).

s1 414 U.S. at 551. 
case would have created. This goal would not require the prevention of all protective motions, but only the prevention of situations in which substantially all class members file protective motions, because such an occurrence would "deprive Rule 23 of the efficiency and economy of litigation which is a principal purpose of the procedure." ${ }^{\text {'32 }}$ If all class members were to file protective motions, the suit would no longer be a class suit at all, but a joint suit with every class member present in court. In other words, a multiplicity of activity would destroy the utility of the class action device.

This second interpretation of American Pipe is more consistent with the overall rationale of the case. The Court's concern throughout was the preservation of the class action device, not the elimination of all wasteful motions. The Court had held earlier in American Pipe that class members in a suit granted class certification after the statute of limitations had expired were protected from the statute of limitations. Its reason for this rule was that otherwise every class member would have to file a motion to join or intervene to benefit from the class action..$^{3 s}$ It was using the same rationale later when discussing class suits denied certification after the running of the statute. ${ }^{34}$ The Court described this rule as necessary for the preservation of the class action device. ${ }^{35}$ The filing of a few protective motions does not threaten that procedure.

2. Notice. The notice issue may take two forms. In the first, the defendant would assert that the class claim was incomprehensibly vague. He may have received notice of the named plaintiff's claims within the statutory period, while having absolutely no idea what sort of class he was opposing. The defendant would thus claim that he was unable to determine "both the subject matter and size of the prospective litigation" ${ }^{\text {"s6 }}$ within the statutory period, and accordingly did not receive notice adequate to justify tolling the statute of limitations for any asserted class members. This problem could arise if the named plaintiff made a vague allegation of injury, and then claimed to sue on behalf of himself "and all others similarly situated."

Such class claims will be rare, however. A number of federal

\footnotetext{
32 Id. at 553.

23 Id. at 551 .

s Id. at 553 .

$33 \mathrm{Id}$. at 556.

se Id. at 555 .
} 
district courts have adopted local rules requiring any class action complaint to include detailed allegations of fact as to the size and definition of the alleged class, and the common questions of law or fact that unite the class. ${ }^{37}$

The second notice problem would involve only some class members. The complaint may assert a specific class, but some class members subsequently may be revealed to have distinguishing characteristics that would substantially affect the defendant's case. $^{38}$ The defendant thus would assert that he had been surprised by claims he was not prepared to defend against.

If courts should deny American Pipe tolling benefits to these putative class members because elements of their claims varied significantly from that of the class, some protective motions would be filed in subsequent class suits in which the statute of limitations was about to expire. Asserted class members whose claims varied in what might be significant ways from those of the rest of the class would file protective motions to join or intervene, fearing that

${ }^{37}$ Twenty-five districts have adopted such a rule. That of the Southern District of New York is typical:

In any action sought to be maintained as a class action:

(b) The complaint (or other pleading asserting a claim for or against a class) shall contain next after the jurisdictional grounds and under the separate heading 'Class Action Allegations':

(2) Appropriate averments to justify such claim-including, but not necessarily limited to,

(i) the number (or approximate number) of members of the class,

(ii) a description of the members of the class,

(iii) the basis upon which it is claimed that the party asserting the claim will fairly and adequately protect the interests of the class, or, if the claim is asserted against a class, that the named members of the class will fairly and adequately protect the interests of that class,

(iv) the questions of law or fact claimed to be common to the class, and

(v) in actions claimed to be maintainable as class actions under subdivision (b)(3) of Fed $\mathrm{R}$ Civ $\mathrm{P} 23$, averments to support the findings required by that subdivision, including those noted under (A), (B), (C) and (D) of the subdivision.

S.D.N.Y. Crv. R. 11A. Accord, E.D. CAL. Crv. R. 124; S.D. CaL. Crv. R. 200-4; D.D.C. Crv. R. 1-13; S.D. FLA. R. 19; N.D. FLA. R. 17; M.D. FLA. R. 4.04; N.D. GA. R. 220; S.D. GA. R. 14; S.D. ILL. R. 28; S.D. IND. R. 7; E.D. LA. R. 2.12; W.D.N.Y.R. 8; S.D. OHo R. 3.9; N.D. OHo R. Complex Litigation 3.01; D. ORe. R. 17; E.D. PA. R. 45; M.D. PA. R. 701.07; W.D. PA. R. 34; D.R.I.R. 30; M.D. TENn. R. 14; D. VT. R. 11; E.D. WASH. R. 7; W.D. WASH. Crv. R. 23.

${ }^{28}$ For example, in McCarthy v. Kliendienst, 562 F.2d 1269 (D.C. Cir. 1977), the class asserted was all those illegally arrested and maliciously prosecuted as a result of a political demonstration. It subsequently appeared, however, that some of the class members had been arrested under different conditions, which would require different types of evidence. Id. at 1275. See text and note at note 28 supra. 
they might be denied American Pipe tolling benefits because the defendant had no notice of their claims. These anxious class members would comprise small elements of the class, however. This kind of notice problem would result in the filing of protective motions, not by the entire class, but by only a few members. The possibility of a few protective motions is not the "multiplicity of activity" that the American Pipe Court sought to avoid. ${ }^{39}$

As a practical matter, then, the question of adequate notice to the defendant will not come up very often. Even when it does arise, it will affect only a few members of the asserted class.

3. Resolution. The two requirements of American Pipe thus can be applied consistently. The courts should consider whether the defendant had notice of the claims presented. This analysis will involve the consideration of subtle factors, but the question will arise in only a few cases, and it will affect only a few asserted class members. As such, the notice question will not foster the multiplicity of activity that concerned the Court.

\section{The Proper Method of Tolling}

\section{A. Methods of Tolling}

There are three ways in which a statute of limitations can be "tolled": it can be postponed, suspended, or extended. ${ }^{40}$ In cases of fraud, where the plaintiff could not discover the fraud for some time, or of fraudulent concealment by the defendant after the cause of action arose, the limitation period is deemed not to have begun running, that is, to be postponed, until the plaintiff reasonably could be expected to have discovered his injury. ${ }^{11}$ The statute is suspended when the clock has begun to run, but is stopped as long as some condition prevails, and will begin running again as soon as that condition is lifted. An example of suspension occurs when the defendant flees the jurisdiction. As soon as the defendant returns, the statutory period begins to run again. ${ }^{12}$ The period is extended after the expiration of the normal period, if the plaintiff is deemed to deserve an extra unit of time in which to bring his action.

3o See text and notes at notes 29-35 supra.

10 See generally Statutes of Limitations, supra note 24, at 1220-37. 1210-22.

4 See generally Dawson, supra note 23; Statutes of Limitations, supra note 24, at

121 H. Wood, Limfation of Actions 1070-1195 (4th ed. 1916); Statutes of Limitations, supra note 24 , at $1222-34$. 
The Supreme Court applied a form of extension in United Airlines, Inc. v. McDonald.43 In that case asserted class members sought to intervene after the entry of final judgment in the representative's individual action, in order to appeal the denial of class certification. Although the statute of limitations had long since expired, the court held that asserted class members should be granted a reasonable period of time after the entry of final judgment in which to intervene in order to appeal the denial of certification. ${ }^{44}$

\section{B. American Pipe}

The decision in McDonald to toll by extension may be contrasted with American Pipe's rule of suspension. In American Pipe the Court reasoned by analogy from section 5(b) of the Clayton Act, ${ }^{45}$ which tolls the statute of limitations for private antitrust suits during the pendency of a federal government suit. Since that statute "suspends" the limitation period during a government suit, the Court reasoned, the period in this case should be considered suspended during the pendency of the class suit. ${ }^{46}$

The Court's reading of section 5(b) of the Clayton Act was incorrect, however. That section does not suspend the statutory period during a government suit, but rather provides for extension. ${ }^{47}$ The original section of the Act did provide for a simple sus-

4342 U.S. 385 (1977).

4 Id. at $395-96$.

45 U.S.C. $\$ 16(\mathrm{~b})$ (1976); see note 47 infra.

16 414 U.S. at 561. It is not clear precisely what analogy the Court was drawing from the Clayton Act. It may have been comparing antitrust class actions with government suits: antitrust policy would be better enforced if asserted class members could await the results of any class action, and reap all possible benefits from it, as they can now from a government suit. Alternatively, given its decision to toll the statute of limitations in class actions, the Court might have been asking which form of tolling was most consistent with congressional policy; given such a choice, Congress has expressed a preference for suspension, when a limitation period is to be tolled.

17 Whenever any civil or ciminal proceeding is instituted by the United States to prevent, restrain, or punish violations of any of the antitrust laws, but not including an action under section $15 \mathrm{a}$ of this title, the running of the statute of limitations in respect of every private right of action arising under said laws and based in whole or in part on any matter complained of in said proceeding shall be suspended during the pendency thereof and for one year thereafter: Provided, however, That whenever the running of the statute of limitations in respect of a cause of action arising under section 15 of this title is suspended hereunder, any action to enforce such cause of action shall be forever barred unless commenced either within the period of suspension or within four years after the cause of action accrued.

Clayton Act $\S 5(b), 15$ U.S.C. $\S 16(b)$ (1976) (emphasis in original). 
pension of the limitation period during a government suit. ${ }^{48}$ In 1955, however, Congress amended that section, allowing the plaintiff one year after the termination of a government suit, or the normal four years after his cause of action arose, whichever is greater. ${ }^{49}$ Congress felt that a simple suspension provision was unjust:

There are many instances where the statute of limitations as to a private cause of action may nearly have expired before suit is instituted by the Government under the antitrust laws. Although the statute is tolled during the pendency of the proceedings brought by the United States, the plaintiff in a treble-damage action may find himself hard pressed to reap the benefits of the Government suit if, upon its conclusion, he has but a short time remaining to study the Government's case, estimate his own damages, assess the strength and validity of his suit and prepare and file his own complaint. ${ }^{.0}$

\section{Extension and Suspension in Class Suits}

A hardship similar to that imposed on antitrust plaintiffs by suspension can be visited upon asserted class members by American Pipe's suspension rule. In American Pipe itself, for example, asserted class members had only eleven days ${ }^{51}$ in which to learn of the denial of certification, ${ }^{52}$ to decide whether the prospective individual recovery was worth the time and expense of filing such a motion, and to take such action if appropriate.

The difficulty of the asserted class members' position is exac-

48 Whenever any suit or proceeding in equity or criminal prosecution is instituted by the United States to prevent, restrain or punish violations of any of the antitrust laws, the running of the statute of limitations in respect of each and every private right of action arising under said laws and based in whole or in part on any matter complained of in said suit or proceeding shall be suspended during the pendency thereof.

Clayton Act, ch. 323, § 5, 38 Stat. 731 (1914) (amended 1955).

- Act of July 7, 1955, ch. 283, \& 2,69 Stat. 283 (codified at 15 U.S.C. $\S 16$ (b) (1976)).

so S. REP. No. 619, 84th Cong., 1st Sess. 6 (1955), reprinted in [1955] U.S. CodE CoNG.

\& AD. News 2328, 2332.

s1 414 U.S. at 561.

${ }^{82}$ It is not reasonable to expect that asserted class members will be notified by the class representative when class certification is denied, so that the asserted class members could act to protect their interests. This did happen in American Pipe, see Utah v. American Pipe \& Constr. Co., 50 F.R.D. 99, 100 (C.D. Cal. 1970), but the representative in that case was the Utah state government, which had an independent duty to protect the interests of public agencies in Utah. Furthermore, the representative notified only public agencies in Utah, and none from other states. Thus, out of a class of approximately 350 members, as the trial court described it, 49 F.R.D. at 21, the representative notified only 60 members. 
erbated by the possibility of appeals of the denial of class certification. A prompt motion to intervene would be unnecessary if the representative should appeal, or if the class members could successfully appeal the denial of class certification after the entry of final judgment. ${ }^{53}$ As a result, class members need to consider these additional factors when deciding whether to intervene within the suspension period offered by American Pipe.

Because of these difficulties, the suspension rule of American Pipe is inconsistent with the rationale of McDonald. The Court in $M c D o n a l d$ reasoned that, unless asserted class members were allowed a period of time to discover that the representative would not appeal, asserted class members would move to intervene immediately after the denial of certification, in order to avoid the possibility that the representative might not appeal. The result would be the multiplicity of motions in a class suit condemned by the Court in American Pipe. ${ }^{54}$ Yet the suspension rule of American Pipe undercuts this rationale. When the asserted class member is given very little time to evaluate his situation-as can happen with suspension-he must file a motion to intervene, although he might have become convinced such a motion was unnecessary, had the asserted class member had time to investigate the likelihood that the representative would appeal, or the probability of winning an appeal of the certification question on his own.

\section{Protection of Defendants}

Congress further recognized that suspension could work unfairly against defendants as well. A simple suspension provision could keep claims alive several years after the termination of a

${ }^{53}$ If the representative should appeal the denial of certification and win, the class action will proceed without any problem with the statute of limitations because the reversal of the denial of certification relates back to the filing of the complaint. Knable v. Wilson, 570 F.2d 957, 964 n.46 (D.C. Cir. 1977); Gelman v. Westinghouse Elec. Corp., 556 F.2d 699, 70102 (3d Cir. 1977). Even if the representative should appeal the denial of certification and lose, the statute will continue to toll until the appeal is lost. Jimenez v. Weinberger, 523 F.2d 689, 696 (7th Cir. 1975), cert. denied, 427 U.S. 912 (1976). Thus, if the asserted class members are convinced that the representative will appeal, they need not move promptly to intervene, because the appeal will keep the statute tolling.

Further, the class members need not move to intervene within the American Pipe suspension period if they could successfully appeal the denial of certification themselves after the entry of final judgment in the representative's individual suit. United Airlines, Inc. v. McDonald, 432 U.S. 385 (1977). If the class members should lose on appeal, however, they will be barred by the statute of limitations from bringing individual suits.

s4 432 U.S. at 394 n.15. 
protracted government suit. ${ }^{55}$ This same unfairness in class suits is exemplified by several cases applying American Pipe's suspension rule. In these cases the lapse between filing and the certification decision was several years, and the statutory period at the time of suspension still had several years remaining. Plaintiffs could then file suits as much as two years after the denial of certification, claiming the tolling benefits of American Pipe. ${ }^{56}$ Under the simple suspension provisions of American Pipe, these plaintiffs were protected. Yet nothing in the rationale of that case requires the protection of these plaintiffs. They obviously were not relying on the class suit to protect their rights, and thus would not have filed protective motions to join or intervene had they not been protected by the American Pipe tolling rule.

\section{E. Suspension As Opposed to Extension}

Suspension is an arbitrary and inflexible method of tolling that has no inherent attraction other than its simplicity in application. When the suspension ceases, the potential litigant has only the time remaining in the original limitation period-the time left when suspension was imposed-in which to act. This allowance of time bears no relation at all to the needs of the litigant or the requirements of the case. Extension is a more logical and equitable method of tolling because it does not depend on the amount of time left over from the original limitation period: under extension a court makes a new grant of time, regardless of how much of the statutory period has expired. Tolling by extension can be tailored to the needs of the parties in the individual case. For this reason the courts should require plaintiffs claiming American Pipe tolling benefits to do so within some reasonable time after the denial of class action status. ${ }^{\text {st }}$

ss S. REP. No. 619, 84th Cong., 1st Sess. 6 (1955), reprinted in [1955] U.S. Code Cong. \& AD. Nkws 2328, 2332-33.

ss See, e.g., Stull v. Bayard, 561 F.2d 429 (2d Cir. 1977), cert. denied, 434 U.S. 1035 (1978). The class suit remained pending for two years before class certification was denied. Fifteen months after the entry of that order, and five months after the statutory period had expired, some asserted class members filed separate suits, claiming American Pipe tolling benefits.

${ }^{37}$ The Supreme Court criticized judicial tolling by extension in Burnett v. New York Cent. R.R., 380 U.S. 424 (1965). The plaintiff brought an FELA action in an Ohio state court, and that court subsequently dismissed the suit for improper venue after the statute of limitations had run. The Court held that the statute would be suspended during the pendency of the suit, and during the period until further appeals were either exhausted or timebarred. The Court reviewed and rejected other possible forms of tolling, concluding that 


\section{Methods of Claiming Tolling Benefits}

The aspect of American Pipe that has generated the most controversy concerns how the asserted class members may claim tolling benefits. Specifically, asserted class members may try to claim such benefits by filing a separate suit, or by moving to join or intervene in the class representative's suit, which is now proceeding as an individual claim. American Pipe is contradictory on this point. The Court seems to have given two versions of its holding. The first was narrow and extended tolling benefits only to those asserted class members who moved to intervene in the suit, as the plaintiffs in American Pipe had. ${ }^{58}$ There is a second, broader ver-

to toll the federal statute for a "reasonable time" after the state court orders the plaintiff's action dismissed would create uncertainty as to exactly when the limitation period again begins to run. This uncertainty would be compounded by applying the equitable doctrine of "laches" ... . Whether laches bars an action in a given case depends upon the circumstances of that case and "is a question primarily addressed to the discretion of the trial court." To apply it here would be at variance with the policies of certainty and uniformity underlying this statute of limitations.

Id. at 435 (quoting Gardner v. Panama R.R., 342 U.S. 29, 30 (1951)). The Court thus apparently criticized extension by a reasonable time as uncertain and nonuniform.

Those criticisms are not relevant to the class action context. The Court's concern with uniformity was based on the need for a uniform application of FELA. See 380 U.S. at 433. That concern thus does not apply here. Also, the Court's concern over uncertainty in that situation does not apply with equal force to class actions. In Burnett, tolling by suspension produced none of the unfairness that occurs in the class action situation. There is no unfairness to the plaintiff. He needs only enough time to file a new suit in the proper court; he does not need time to learn of his predicament, to evaluate his situation, and to decide on a course of conduct. There was also less unfairness to the defendant in Burnett as a result of suspension. The defendant was thoroughly aware of the one suit outstanding against him, and knew that that suit would soon be brought in another court. Any unreasonable delay allowed by suspension would not prejudice the defendant as severely. The defendant's only uncertainty in a Burnett-type situation is when the one suit will be filed against him, and not whether and how many suits will be filed against him, as is true in the class action situation. In such a situation, therefore, the uncertainty of extension by a reasonable time would appear as a significant drawback; in the class action situation, however, such uncertainty is unimportant when compared with the unfairness of suspension.

${ }^{s} \mathrm{~B}$ We hold that in this posture, at least where class action status has been denied solely because of failure to demonstrate that "the class is so numerous that joinder of all members is impracticable," the commencement of the original class suit tolls the running of the statute for all purported members of the class who make timely motions to intervene after the court has found the suit inappropriate for class action status.

414 U.S. at 552-53 (emphasis added) (quoting FED. R. Crv. P. 23(a)(1)). See also id. at 555 (emphasis added):

Within the period set by the statute of limitations, the defendants have the essential information necessary to determine both the subject matter and size of the prospective litigation, whether the actual trial is conducted in the form of a class action, as a joint suit, or as a principal suit with additional intervenors.

Following this language, Professor Moore believes that American Pipe benefits only inter- 
sion of the Court's holding, however, which does not contain such a restriction. ${ }^{50}$

\section{A. Judicial Interpretations}

Several courts, including the Second Circuit, have adopted the more restrictive interpretation of American Pipe and allowed only intervenors to claim tolling benefits. These courts have relied on the "multiplicity" consideration of American Pipe. ${ }^{60}$ They read that case to disapprove of all duplicative suits as contrary to the purpose of rule 23. Because separate suits would be duplicative, the purposes of American Pipe would not be furthered by granting tolling benefits to these suits, and thus American Pipe's tolling rule does not apply. ${ }^{\text {i1 }}$

This rationale misapplies the "multiplicity" concept. The Supreme Court's concern was not with protective motions per se, but only with a vast number of them that would render the class action superfluous. ${ }^{62}$ It is one thing to seek to prevent a flurry of protective motions that would destroy the efficacy of the class action device; it is quite another to insist that the smallest possible number of suits be brought in resolving a dispute.

The other courts have not restricted tolling benefits to intervenors, ${ }^{6 s}$ and indeed there is nothing in the rationale of American

venors. 3B J. Moore, Fedrrat Practice II 23.90[3], at 23-555 n.16 (2d ed. 1976).

38 We are convinced that the rule most consistent with federal class action procedure must be that the commencement of a class action suspends the applicable statute of limitations as to all asserted members of the class who would have been parties had the suit been permitted to continue as a class action.

414 U.S. at 554 (footnote omitted).

60 Stull v. Bayard, 561 F.2d 429 (2d Cir. 1977), cert. denied, 434 U.S. 1035 (1978), Arneil v. Ramsey, 550 F.2d 774 (2d Cir. 1977); Jefferson v. H.K. Porter Co., 485 F. Supp. 356, 360-61 (N.D. Ala. 1980); Wachovia Bank \& Trust Co. v. National Student Mktg. Corp., 461 F. Supp. 999 (D.D.C. 1978).

-1 Logically, these arguments could apply only to separate suits filed before the denial of certification, although after the running of the statute of limitations. After class certification has been denied, a multiplicity of suits can do no harm to the class action device. The Second Circuit has not so restricted its rule, however, but has also applied it to separate suits filed after the denial of certification. Stull v. Bayard, 561 F.2d 429 (2d Cir. 1977), cert. denied, 434 U.S. 1035 (1978).

62 See text and notes at notes 29-35 supra.

es Satterwhite v. City of Greenville, 578 F.2d 987, 997 (5th Cir. 1978), vacated, 445 U.S. 940 (1980); McArthur v. Southern Airways, Inc., 556 F.2d 298, 303 (5th Cir. 1977); Sanders v. John Nuveen \& Co., 524 F.2d 1064, 1074 n.28 (7th Cir. 1975); Peritz v. Liberty Loan Corp., 523 F.2d 349, 354 n.5 (7th Cir. 1975); Parker v. Bell Helicopter Co., 78 F.R.D. 507, 513 \& n.2 (N.D. Tex. 1978). 
Pipe to require such a restriction. ${ }^{64}$ The goals of preventing a multiplicity of motions and of adequate notice to the defendant draw no distinction between separate suits and motions to intervene.

\section{B. The Case for Intervention}

There nevertheless are reasons for requiring that all asserted class members seeking to claim American Pipe tolling benefits should file motions to intervene, rather than separate suits.

1. Reasonable time. It has already been argued in this comment that a simple suspension of the statutory period is unfair to both plaintiffs and defendants, and that plaintiffs should be afforded some reasonable time in which to claim tolling benefits. ${ }^{65}$ If this proposal were adopted, however, and asserted class members were to file separate suits, the court hearing the case would then decide whether the suit was brought within a reasonable time after the denial of class certification. If several suits, claiming tolling benefits from the same class suit, were filed in various district courts around the country, there would be a danger of inconsistent

os See Class Actions, supra note 20, at 1449. Some cases draw support for their expansive reading of American Pipe from a footnote in Eisen v. Carlisle \& Jacquelin, 417 U.S. 156 (1977):

Petitioner also argues that class members will not opt out because the statute of limitations has long since run out on the claims of all class members other than petitioner. This contention is disposed of by our recent decision in American Pipe \& Construction Co. v. Utah, 414 U.S. 538 (1974), which established that the commencement of a class action tolls the applicable statute of limitations as to all members of the class.

Id. at 176 n.13. See Satterwhite v. City of Greenville, 578 F.2d 987, 997 (5th Cir. 1978), vacated, 445 U.S. 940 (1980); Peritz v. Liberty Loan Corp., 523 F.2d 349, 354 n.5 (7th Cir. 1975).

The Eisen footnote does not bear on the question discussed in this comment-cases in which class certification is denied after the running of the statute of limitations. In Eisen, class certification had been granted, and the question was the protection of class members who choose to opt out of the class action. With regard to the dual goals of American Pipenotice to the defendant and avoiding multiplicity-the Eisen situation presents a question very different from that discussed in this comment. First, notice was not a question in $E i$ sen. The American Pipe Court held that all class members are protected from the statute of limitations when class certification is granted after the running of the statute. See note 4 supra. In so doing, the Court presumed that the defendant has received adequate notice in such a case. See note 19 supra.

As to "multiplicity," whether class members may or may not opt out after the class is certified should have no effect on the filing of protective motions to join or intervene before the ruling on certification is made.

${ }^{65}$ See text and notes at notes $40-56$ supra. 
decisions as to a reasonable length of time, a situation that would be unfair. ${ }^{86}$

It would be much simpler if all asserted class members seeking tolling benefits were to file motions to intervene in the original suit-the named plaintiff's claim, now stripped of its class action character. The trial judge has discretion to deny any motions to intervene that were not timely filed. ${ }^{67}$ Using this discretion, a single judge hearing motions to intervene that claimed American Pipe tolling benefits could decide whether those motions were filed in a reasonable time. The judge would be familiar with the case, and could make the most informed decision possible as to whether the delay in filing a motion to intervene was reasonable in the given instance.

2. Notice. When questions of adequate notice to the defendant do arise, a judge who is thoroughly familiar with the facts and circumstances of the case could make decisions as to notice much more easily. In addition, a judge hearing a suit with intervenors has discretionary control over the issues and claims the intervenors may present. As Justice Blackmun noted in his concurrence to American Pipe, ${ }^{68}$ a judge hearing a suit with intervenors could use his discretion to ensure that only those claims of which the defendant had timely notice would be presented.

\section{Conclusion}

American Pipe left open many questions concerning the vexing problem of suits denied class certification after the running of the statute of limitations. The lower courts, in struggling with the problem, often have failed to comprehend the Court's entire rationale, or have become entangled in American Pipe's confusing and often contradictory language. This comment has dealt with three of those resulting problems. A conflict in the dual goals of American Pipe, as interpreted by the lower courts, can be resolved

co There might follow appeals from such inconsistent cases, with each losing party pointing to the other case to prove an abuse of the trial court's discretion. The final result of a number of such suits might be that the courts would come to agree on some fixed amount of time for all cases involving American Pipe tolling benefits. This would not be a good resolution of the problem, however. As with any arbitrary rule, such a fixed time period inevitably would exclude some deserving plaintiffs, and grant tolling benefits to other plaintiffs who had delayed unreasonably. Efforts to "toll" this judicial statute of limitations would result in still more appeals and wasted judicial resources.

67 Fed. R. Civ. P. 24(b).

as 414 U.S. at 561-62 (Blackmun, J., concurring). 
through a closer reading of the rationale of that case, permitting the vitality of the class action device to be preserved while ensuring adequate timely notice to the defendant. The Court's simple suspension of the statute of limitations during the pendency of the class suit is unfair to both plaintiffs and defendants. Finally, this comment argues that, asserted class members wishing to claim American Pipe tolling benefits should be required to intervene, rather than be allowed to file separate suits. Perplexing questions remain in the administration of class actions, but the proper application of the statute of limitations need not be one of them.

Charles F. Sawyer 